\title{
The Idea of Prevention and Settlement of Human Rights violations in the Field of Natural Resources Based on Local Wisdom
}

\author{
Muh. Risnain \\ Faculty of Law, Universitas Mataram, Indonesia, Email: risnain82@gmail.com
}

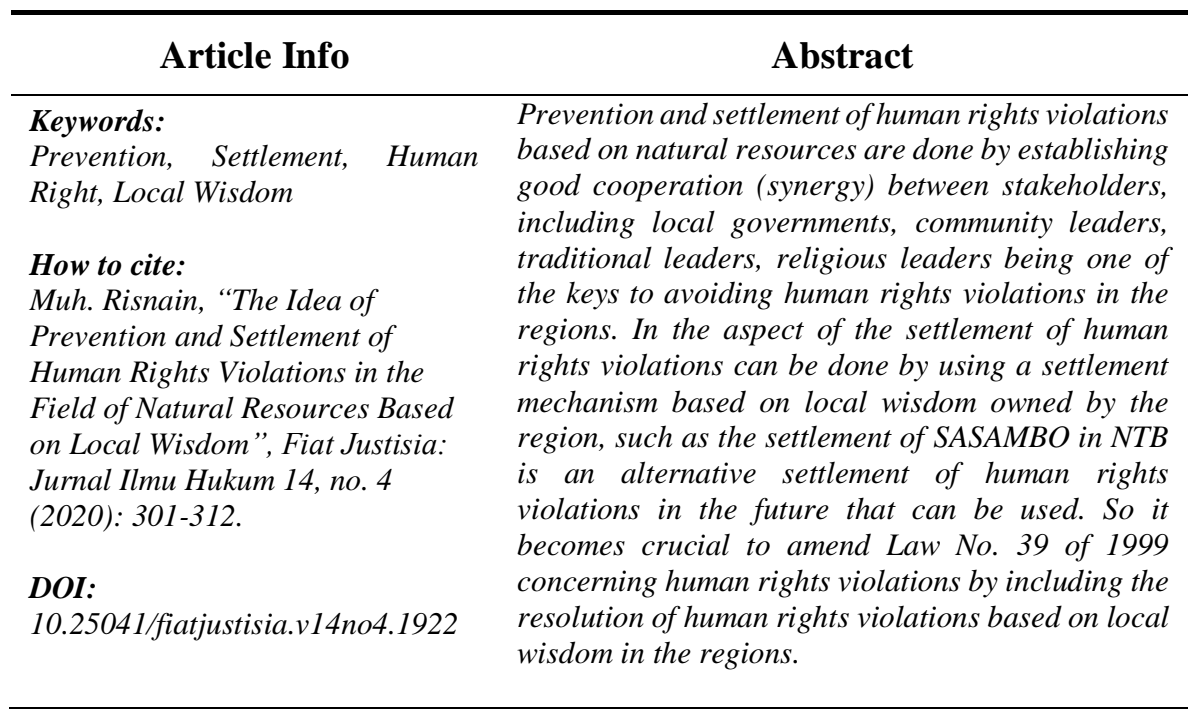

\section{A. Introduction}

The expanding of the tourism, mining, and plantation, marine and fisheries industries in West Nusa Tenggara or Nusa Tenggara Barat (NTB) is expected to bring prosperity to the people of NTB. Still, at the same time, other problems arise, vertical conflicts based on natural resource management mainly mineral, forestry and coastal resources which even led to the issue of alleged human rights or hak asasi manusia (HAM) violations is a fact that cannot be denied. Cases such as land ownership conflicts in the Mandalika area managed by the Indonesian Tourism Development Center (ITDC), Central Lombok, the Lombok International Airport area, Sekaroh forest area, the bloody Lambu tragedy of Bima District in 2012 are clear examples of vertical conflicts that led to the issue of human rights violations. Based on the report of the NTB Representative of Ombudsman of the Republic of Indonesia (ORI), there have been 203 cases of reports of community mal-administration 
violations to ORI NTB since 2017. A large number of cases are a formidable challenge faced by local governments, which must stand on two different interests, the interests of investment conditionality and the importance of protecting the rights of the community.

As a province that relies on the mainstay sector of the tourism industry, investment becomes a much-needed thing in the regional economy. Still, at the same time, a vertical conflict between the community and investors or SOEs is something that can hamper investment conditionality. It gets worse when the conflict is then indicated or comes to the issue of alleged human rights violations. The impact is not only on the sustainability of investments but also on humanitarian issues.

Vertical conflict based on natural resources is not an expected situation by stakeholders, local governments, investors, communities, and the central government. It is a reality that must be prevented and resolved elegantly and. Prevention of human rights violations to minimize the potential for conflict between investors and the public. The settlement of human rights violations to resolve alleged human rights violations based on the applicable laws and regulations so that human rights violations do not occur protracted and provide protection for victims of human rights violations ${ }^{1}$.

The settlement of human rights violations through applying Law No. 39 of 1999 concerning human rights ${ }^{2}$ in and outside court did not always solve the problem completely, especially concerning natural resources. Therefore, we need a new model for resolving human rights violations based on natural resource conflicts in the regions using an alternative approach ${ }^{3}$. The approach in question is an approach based on local wisdom ${ }^{4}$.

The NTB community is inhabited by three prominent tribes which are Sasak, Samawa, and Mbojo (SASAMBO). SASAMBO are people who will intersect with investment activities that are also potential victims of human rights violations. It is vital to explore and use the potential of the local wisdom values of the SASAMBO community to prevent and resolve potential human rights violations in NTB. This idea will certainly be adjusted to human rights violations settlement mechanisms that are recognized and regulated in Law No. 39 of 1999 concerning human rights.

\footnotetext{
${ }^{1}$ Sulaiman, "Rekonsiliasi Berbasis Kearifan Lokal di Aceh (Reconciliation Based Local Wisdom in Aceh)", Kanun Jurnal Ilmu Hukum 18, mo. 3, (2016): 367-376.

${ }^{2}$ Lina Hastuti, "Pengadilan Hak Asasi Manusia Sebagai Upaya Pertama dan Terakhir Dalam Penyelesaian Pelanggaran Berat Hak Asasi Manusia di Tingkat Nasional", Jurnal Dinamika Hukum 12, no. 3 (2012): 395-406.

${ }^{3}$ Lorna McGregor, "Alternative Dispute Resolution and Human Rights: Developing a RightsBased Approach through the ECHR", The European Journal of International Law 26, no. 3 (2015): 607-634. https://doi.org/10.1093/ejil/chv039.

${ }^{4}$ Soetandyo Wignjosoebroto, Hukum dan Masyarakat: Perkembangan dan Masalah, Sebuah Pengantar ke Arah Kajian Sosiologi Hukum (Malang: Bayu Media, 2008), 42.
} 
This research is normative legal research. The approach used is the statutory and conceptual approach. The conceptual approach is carried out by examining legal norms regarding the resolution of human rights violations in Indonesian national law starting from the 1945 Republic of Indonesia Constitution, Law No. 39 of 1999 concerning human rights, and Law No. 26 of 2000 concerning human rights courts. The conceptual approach by examining the concept of conflict resolution that applies from the three major tribes in NTB, namely Sasak, Samawa and Mbojo, then the principles of dispute resolution are adopted in settlement of human rights based on natural resources based on a new concept offered in the resolution of human rights violations.

\section{B. Discussion}

\section{Constitutional Design of Prevention and Disputing of Human Violations in Indonesia}

Theoretically, one element of the rule of law is protection and respect for human rights, in addition to equality before the law, judicial independence, and the rule of law ${ }^{5}$. Recognition of human rights is usually recognized in the fundamental law of the country whose name is the constitution. That was later in the 1945 Constitution of the Republic of Indonesia after amendments were explicitly made regulating human rights. Human rights are then regulated in Chapter XXVIII A of the 1945 Constitution of the Republic of Indonesia concerning human rights as a separate chapter that provides recognition of civil and political rights, socio-cultural rights, and the right to development. ${ }^{6}$

Recognition and respect for human rights are then reaffirmed in Article 28 I paragraph (4), which imposes the responsibility of the State to provide protection, promotion, enforcement, and fulfilment of human rights is the responsibility of the State, especially the government ${ }^{7}$. The constitutional order that gives attribution to the government as the primary responsibility holder for the protection, promotion, enforcement, and fulfilment of human

\footnotetext{
${ }^{5}$ Organisation for Economic Co-Operation and Development, "Human Rights, Alternative Dispute Resolution and the OECD Guidelines For Multinational Enterprises", Briefing Note for the Participants at the Workshop on Accountability and Dispute Resolution Kennedy School of Government, Harvard University 11-12 April, (2007).

${ }^{6}$ Knut D. Asplund, Suparman Marzuki, Eko Riyadi, Hukum Hak Asasi Manusia (Yogyakarta: Pusat Studi Hak Asasi Manusia Universitas Islam Indonesia, 2008), 3.

${ }^{7}$ Olivera Vučić, Perspectives of use of alternative dispute resolution techniques in cases of discrimination in Serbia - Second report, United Nations Development Programme, Office in Serbia, Ministry of Labour and Social Policy Project "Support to the implementation of Antidiscrimination Legislation and Mediation in Serbia" funded by the European Union, 2010.
} 
rights requires the government's seriousness and extra work to make it happened. ${ }^{8}$

Constitutional recognition of human rights in the constitution is then limited again by the constitution. ${ }^{9}$ Article 28 I paragraph (4) regulates the principles of upholding and protecting human rights "to uphold and protect human rights in accordance with the principles of a democratic rule of law; therefore, the implementation of human rights is guaranteed, regulated, and stated in legislation". Article 28 J paragraph (1) of the 1945 Constitution then limits that, "Everyone obliged to respect the human rights of others in the orderly life of society, nation and state". In article $28 \mathrm{~J}$ paragraph (2) limits human rights again by, "In exercising their rights and freedoms, every person is obliged to submit to restrictions imposed by law with the intent solely to guarantee recognition and respect for the rights of freedom of others and to fulfil fair demands in accordance with moral considerations, religious values, security and public order in a democratic society".

The regulation and recognition of human rights in the constitution are then re-arranged in Law No. 39 of 1999 concerning Human Rights which defines Human Rights as a set of rights inherent in the nature and existence of human beings as creatures of God. His gifts must be respected, is upheld and protected by the State, law, government, and everyone for the sake of honour and protection of human dignity. This definition then reaffirms the obligation to respect, uphold, and protect human rights to four elements, namely: State, law, and government.

Law No. 39 of 1999 concerning Human Rights promulgated in 1999, although previously enacted from the amendment to the 1945 Constitution of the Republic of Indonesia, provides limits on human rights violations. General provisions explain that "Violations of human rights are any acts of a person or group of people including intentional or unintentional state apparatus or negligence that violates the law by reducing, obstructing, limiting, or revoking the human rights of a person or group of people that are guaranteed by this law, and not obtaining, or feared to not obtaining a fair legal settlement based on applicable legal mechanisms". ${ }^{10}$

According to the authors, the definition of human rights violations indicates that the issue of human rights violations includes the issue of multimode, multi-actors, and multi-forms. Multi-factor shows that human rights violations are acts of a person/group of people, and state apparatus. Multi-

\footnotetext{
${ }^{8}$ Disca Betty Viviansari, “Tanggung Jawab Negara Terhadap Hak Atas Pendidikan Anak Buruh Migran Indonesia di Malaysia", Jurnal HAM 10, no. 2 (2019): 179-194. http://dx.doi.org/10.30641/ham.2019.10.179-194.

${ }^{9}$ Saldi Isra, "Peran Mahkamah Konstitusi Dalam Penguatan Hak Asasi Manusia di Indonesia," Jurnal Konstitusi 11, no. 3 (2014): 1-19. tttps://doi.org/10.31078/Jk\%25x.

${ }^{10}$ Soetandyo Wignosubroto, Hukum: Paradigma, Metode dan Dinamika Masalahnya (Jakarta: Humas dan Elsam, 2002), 461.
} 
mode that human rights violations can be intentional or unintentional or negligence that violates the law to reduce, hinder, limit, or revoke the human rights of a person or group of people guaranteed by Law 39 of 1999 concerning Human Rights.

\section{Completion of Human Violations in the Natural Resources Based on Local Wisdom of West Nusa Tenggara}

The constitutional order that imposes responsibility for the protection, promotion, enforcement, and fulfilment of human rights to the responsibility of the State, especially the government provides a basis for the government to resolve the issue of human rights violations based on natural resource ${ }^{11}$ conflicts in NTB. Still, at the same time, the government must make efforts to prevent human rights violations, especially in the tourism area so that there is no disruption but at the same time do not damage the image of tourism area as a human rights violator. ${ }^{12}$

Although the State primarily bears the responsibility for the protection, promotion, enforcement, and fulfilment of human rights through the government, Article 100-103 of Law No. 39 of 1999 concerning human rights provides opportunities for the public to participate. Article 100 gives the right of every person, group, political organization, community organization, nongovernmental organization, or other social organization to have the right to participate in the protection, enforcement, and promotion of human rights. Article 101 recognizes that every person, group, political organization, community organization, non-governmental organization, or other social organization has the right to submit reports of violations of human rights to the National Human Rights Commission or other authorized institutions for protection, the enforcement, and promotion of human rights. Article 102 gives rights Every person, group, political organization, community organization, non-governmental organization, or another social organization has the right to submit proposals regarding formulations and policies relating to human rights to the national commission on the human right or Komisi Nasional Hak Asasi Manusia (Komnas HAM) and other institutions. Article 103 gives rights to any person, group, political organization, community organization, nongovernmental organization, university, study institution, or other social organization, either individually or in collaboration with the National Human

\footnotetext{
11 United Nations Department Of Political Affairs And United Nations Environment Programme, Natural Resources And Conflict, A Guide For Mediation Practitioners (UN DPA and UNEP, 2015), 11

12 Indra Perwira, in Danrivanto Budhijanto, "Dinamika Hukum dalam Pembangunan Berkelanjutan (Bandung: Alumni dan Universitas Padjadjaran, 2017), 512.
} 
Rights Commission to conduct research, education, and information dissemination on human rights ${ }^{13}$.

Based on the provisions of Articles 100-103 above, it shows three forms of community involvement in protection, promotion, enforcement and fulfilment of human rights first, submitting reports of human rights violations to the National Human Rights Commission or other authorized institutions in the framework for the protection, enforcement, and promotion of human rights, secondly, to submit proposals regarding the formulations and policies relating to human rights to the National Commission on Human Rights or other institutions, third, to conduct research, education, and dissemination of information on human rights.

Thus the principle of protection, promotion, enforcement, and fulfilment of human rights within the framework of the Human Rights Act is the principle of synergy. In such a context, the prevention of human rights violations based on natural resources in NTB should be done in a synergy between various parties such as local governments, communities, nongovernmental organizations, indigenous peoples, and universities.

Two programs carried out by the Ministry of Human Rights through a human rights-friendly city/regency assessment program and regional human rights action plans (RAN HAM) are instruments to prevent natural-based human rights violations in the regions. RAMAH HAM city program by regency/city government is the first entrance to prevent human rights violations by the government. Likewise, with the regional action plan Regional Human Rights (RAN HAM) is an instrument to confirm the commitment of the local government and prevent new violations of human rights based on natural resources in the region.

The settlement of human rights violations in the human rights system in Indonesia only recognizes two mechanisms, namely through the court and outside the court. Through the courts conducted through human rights courts and ad hoc human rights courts. The mechanism outside the court is carried out through the National Human Rights Commission (Komnas HAM) and the Truth and Reconciliation Commission (KKR). National Commission acts to carry out the mediation function as mandated by article 76 of the Human Rights Law. The KKR mechanism is implemented through the establishment of a truth and reconciliation commission. ${ }^{14}$

\footnotetext{
13 Caroline Rees, "Mediation in Business-Related Human Rights Disputes: Objections, Opportunities and Challenges" Corporate Social Responsibility Initiative Working Paper, no. 56 (2010). Cambridge, MA: John F. Kennedy School of Government, Harvard University. Comments may be directed to the author, caroline_rees@ harvard.edu.

${ }^{14}$ Aulia Rosa Nasution, "Penyelesaian Kasus Pelanggaran HAM Berat melalui Pengadilan Nasional dan Internasional serta Komisi Kebenaran dan Rekonsiliasi", Mercatoria 11, no. 1 (2018): 90-126. https://doi.org/10.31289/mercatoria.v11i1.1509.
} 
The model of resolving human rights violations in Law No. 39 of 1999 concerning human rights as well as Law No. 26 of 2000 concerning human rights courts shows the formalization of resolving human rights violations which are limited to formal mechanisms provided by the State, human rights court, national human rights commission and the Truth Commission and Reconciliation (TRC). Even though these three mechanisms are generally ineffective, the human rights court is not easy to form, it needs political support from parliament so that an ad hoc human rights court can be formed. Komnas HAM needs to conduct an in-depth investigation to resolve human rights violations. The TRC has not yet been formed after the Constitutional Court annulled the TRC Law. Therefore, there is a need for other mechanisms to resolve human rights violations in the regions, especially in the field of natural resources, which are based on the values of local wisdom that are owned by the community outside of human rights law and the human rights court as a legal mechanism that aspires to apply in the future (iusconstittuendum).

The author offers a concept of resolving violations based on natural resources by using local wisdom mechanisms that are owned by the community. Incidentally, in NTB, which is inhabited by three large tribes (SASAMBO), there are local wisdom values that can be used to solve social, legal issues and even in the context of modern law such as human rights. The truth is that the three regions inhabited by these three tribes have extraordinary natural resources that have the potential to uncover the issue of human rights violations. On the island of Lombok, which is generally inhabited by Sasak people with natural potential and tourism that is so beautiful and is beginning to stretch again, also has the potential for human rights violations. Likewise, in Sumbawa Regency and West Sumbawa Regency, which is inhabited by the Samawa tribe with extraordinary mining potential, there is also the potential for human rights violations to occur in the mining circle community. Likewise, in the Districts of Bima and Dompu, which have the potential for extraordinary natural resources of mines, has the potential for human rights violations. The Lambu case in 2012 is a clear example of human rights violations, which is a serious problem, both regionally and nationally.

\section{a. Sasaknese Local Wisdom Value in Solving Human Rights Violations}

The idea of resolving human rights violations based on natural resources of the Sasak community is actually adopted from the principle of dispute resolution based on local wisdom that applies to the Sasak community. According to Galang Asmara, the basic principle of dispute resolution in the Sasak community is the establishment of a harmonious atmosphere in the community. Dispute resolution is not intended to find who wins and who loses, but the realization of community peace is the primary goal. The method 
is with consensus agreement between communities and mutual maintain the authority and feelings of the community. ${ }^{15}$

The principles of local wisdom in resolving conflicts in the Sasak community according to Galang Asmara are: First, patut, doing something well, able to distinguish truth and righteousness, secondly, patuh, being obedient, submissive and obedient to the teachings of religion and government, third, pacu, honest and diligent in doing, diligently carrying out the laws of God and the State, fourth, solah, ethical behaviour, fifth, onyak, always careful in acting and words in resolving disputes, sixth, pious, devoted to God, carrying out all his commands and away from the prohibition, seventh, soloh, sincere peace, tolerance in both conduct and behaviour.

\section{b. Samawasnes Local Wisdom Value In Solving Human Rights Violations}

The fundamental values of local wisdom possessed by the Samawasnese are togetherness, deliberation, and consensus. ${ }^{16}$ These values are reflected in the symbols of local wisdom that live in a society such as the following expressions: First, bosangbarisi, ramangberek, means that in resolving conflicts, there are no winners and losers. Second, senapsemu, nyamannyawe, pseudo, comfortable life. Desired community life is an orderly, peaceful, calm, and harmonious society. Third, riamremonyawannyawe, there is togetherness in social life. Fourth, kanyungmanisnalangsungkakan, pitnalangsungbolang, contained the message of caution in behavior, speaking in social life. Fifth, surulalokelengdatang, enengbeang, contained the message that the community must obey and submit to the government and mutual respect and respect with other peoples ${ }^{17}$.

\section{c. Mbojonese/Bimanese Local Wisdom Value In Solving Human Rights Violations}

The Mbojo tribe, for example, has local wisdom to resolve conflicts between citizens with a "mboloradampa" mechanism as a mechanism to solve legal problems based on the spirit of consensus and restorative justice..$^{18}$ This mechanism involves community leaders, religious leaders, traditional leaders, and the government to find the best solution to solve the existing problems. In the end, it produces a grand agreement that is obeyed together and is binding as a law for the parties to the conflict in it. That is the essence of resolving

\footnotetext{
${ }^{15}$ Galang Asmara, "Penyelesaian Konflik Pertanahan Berbasis Nilai-Nilai Kearifan Lokal di Nusa Tenggara Barat," Jurnal Mimbar Hukum 22, no. 1 (2010): 1-200. https://doi.org/10.22146/jmh.16215.

${ }^{16}$ Ibid.

17 Muhammad Sood, "Nilai-Nilai Kearifan Lokal Hukum Adat Samawa yang Menunjang Pembangunan Hukum", Paper Conference faculty of Law, Universitas Mataram, (2005), 16.

${ }^{18}$ M. Natsir, Pranata Lokal dalam Penyelesaian Konflik Sosial di NTB (Mataram: Pustaka Bangsa, 2014).
} 
violations of human rights in restoring the rights of victims and reharmonizing relations between the State and society. ${ }^{19}$

To realize the idea of resolving human rights violations based on local wisdom is not easy. It is necessary to struggle for recognition and respect for the State through legislation. The positive law currently in force only recognizes the settlement mechanism inside and outside the court. Courts go through the human rights court while outside the court, mediation by the National Commission on Human Rights, and through a truth and reconciliation commission is a mechanism which from the procedural side has the flexibility to resolve human rights violations.

In my opinion, the writer needs state recognition of the mechanism of resolving human rights violations based on local wisdom. The path of state recognition is by making arrangements for the settlement of violations of human rights based on local wisdom in the amendment of Law No. 39 of 1999 concerning human rights. This idea is in line with the federal legislation that is being taken by the president and the House of Representatives who have adopted a Bill on Amendments to Law No. 39 the Year 1999 concerning Human Rights in the 2020-2024 national legislation program. In this change, according to the author, it should add a mechanism for resolving human rights violations by including local wisdom owned by the region in resolving human rights violations, especially related to natural resources.

This idea not only contributes to the development of national human rights law, ${ }^{20}$ but It also contributes to the development of international human rights law that provides alternative dispute resolution mechanisms that have so far been practised by other countries such as human rights courts and truth and reconciliation commissions ${ }^{21}$

\section{Conclusions and Recommendations}

The issue of human rights violations against natural resources in an area not only has an impact on the degradation of the most fundamental human rights but more importantly is to maintain the image of the region so that it does not become smeared as an area with the prediction of human rights violators which results in a lack of investment interest and a decrease in the interest of visitors to visit the area. Therefore, maintaining the prevention of human rights violations in the regions is far more critical than allowing human rights violations to occur.

\footnotetext{
${ }^{19}$ Arihan Ahmad Zuber, Bagus Haryono, "Resolusi Konflik Komunal Antara Masyarakat Desa Ngali Dan Renda Kecamatan Belo, Kabupaten Bima Provinsi Nusa Tenggara Barat (NTB) Sodality," Jurnal Sosiologi Pedesaan 6, no. 2 (2018): 146-154. https://doi.org/10.22500/sodality.v6i2.23236.

${ }^{20}$ Yasona H Laoly, in Danrivanto Budhijanto, Op. Cit., 139.

${ }^{21}$ Bagir Manan, in Danrivanto Budhijanto, Op. Cit., 26.
} 
Prevention of human rights based on human rights violations is done by establishing good cooperation (synergy) between stakeholders, including local governments, communities, NGOs, community leaders, traditional leaders, and religious leaders being one of the keys to avoiding violating human rights in the regions. Dispute Settlement using the method of values of wisdom mechanism has advantages because it contained aspects of restorative justice that provide legal certainty, justice, and benefits not only for perpetrators and victims of human rights violations but also society and the State. District /city-friendly human rights policies and regional human rights Action Plans are an entry point for preventing natural-based human rights violations. In the aspect of the settlement, Human rights violations can be done by using settlement mechanisms based on local wisdom owned by the region, such as the settlement of SASAMBO tradition in NTB, which can be used as an alternative solution for future human rights violations. So it becomes essential to amend Law No. 39 of 1999 concerning human rights violations by including the resolution of human rights violations based on local wisdom/institutions in the regions.

\section{References}

Asmara, Galang. "Penyelesaian Konflik Pertanahan Berbasis Nilai-Nilai Kearifan Lokal di Nusa Tenggara Barat". Jurnal Mimbar Hukum 22, no. 1, 2010: 1-200. https://doi.org/10.22146/jmh.16215.

Budhijanto, Danrivanto. Dinamika Hukum dalam Pembangunan Berkelanjutan. Bandung: Alumni dan Universitas Padjadjaran, 2017.

Isra, Saldi. "Peran Mahkamah Konstitusi Dalam Penguatan Hak Asasi Manusia di Indonesia”. Jurnal Konstitusi 11, no. 3, 2014: 409-427. https://doi.org/10.31078/jk\%25x

Knut D. Asplund, Suparman Marzuki, Eko Riyadi. Hukum Hak Asasi Manusia. Yogyakarta: Pusat Studi Hak Asasi Manusia Universitas Islam Indonesia, 2008.

Law No. 24 of 2000 Concerning Human Rights Courts.

Law No. 39 of 1999 Concerning Human Rights.

McGregor, Lorna. "Alternative Dispute Resolution and Human Rights: Developing a Rights-Based Approach through the ECHR," The European Journal of International Law 26, no. 3, 2015: 607-634. https://doi.org/10.1093/ejil/chv039.

Nasution, Aulia Rosa. "Penyelesaian Kasus Pelanggaran HAM Berat melalui Pengadilan Nasional dan Internasional serta Komisi Kebenaran dan Rekonsiliasi”, Mercatoria 11, no. 1, 2018: 90126. https://doi.org/10.31289/mercatoria.v11i1.1509. 
Natsir, M. Pranata Lokal dalam Penyelesaian Konflik Sosial di NTB. Mataram: Pustaka Bangsa, 2014.

Olivera Vučić, Perspectives of use of alternative dispute resolution techniques in cases of discrimination in Serbia - Second report, United Nations Development Programme, Office in Serbia, Ministry of Labour and Social Policy Project "Support to the implementation of Anti-discrimination Legislation and Mediation in Serbia" funded by the European Union, 2010.

Organisation for Economic Co-Operation and Development, "Human Rights, Alternative Dispute Resolution And The Oecd Guidelines For Multinational Enterprises", Briefing Note for the Participants at the Workshop on Accountability and Dispute Resolution Kennedy School of Government, Harvard University 11-12 April, 2007.

Rees, Caroline. "Mediation in Business-Related Human Rights Disputes: Objections, Opportunities and Challenges" Corporate Social Responsibility Initiative Working Paper, no. 56, 2010. Cambridge, MA: John F. Kennedy School of Government, Harvard University. Comments may be directed to the author, caroline_rees@harvard.edu.

Sood, Muhammad. "Nilai-Nilai Kearifan Lokal Hukum Adat Samawa yang Menunjang Pembangunan Hukum”. Paper Conference in Faculty of Law, Universitas Mataram, 2005.

Sulaiman, "Rekonsiliasi Berbasis Kearifan Lokal di Aceh (Reconciliation Based Local Wisdom In Aceh)", Kanun Jurnal Ilmu Hukum 18, no. 3, 2016: 367-376.

United Nations Department of Political Affairs and United Nations Environment Programme, Natural Resources and Conflict, a Guide for Mediation Practitioners, UN DPA and UNEP, 2015.

Viviansari, Disca Betty. "Tanggung Jawab Negara Terhadap Hak Atas Pendidikan Anak Buruh Migran Indonesia di Malaysia." Jurnal HAM 10, No. 2, (2019): $179-194$. http://dx.doi.org/10.30641/ham.2019.10.179-194.

Wignjosoebroto, Soetandyo. Hukum dan Masyarakat: Perkembangan dan Masalah, Sebuah Pengantar ke Arah Kajian Sosiologi Hukum. Malang: Bayu Media, 2008.

Wignosubroto, Soetandyo. Hukum: Paradigma, Metode dan Dinamika Masalahnya. Jakarta: Humas dan Elsam, 2002.

Zuber, Arihan Ahmad., Bagus Haryono. "Conflict Resolution Between of Renda Villagers and Ngali, Belo Subdistrict, Bima Regency of 
the Province of West Nusa Tenggara (NTB)". Sodality: Jurnal Sosiologi Pedesaan 6, no. 2, 2018: 146-154. https://doi.org/10.22500/sodality.v6i2.23236. 